Proceedings

\title{
Images of Perugia
}

\section{Drawings of the City of the Schools of Architecture and Perspective of the "Pietro Vannucci" Academy of Fine Arts of Perugia ${ }^{\dagger}$}

\author{
Luca Martini \\ "Pietro Vannucci" Academy of Fine Arts of Perugia, 06123 Perugia, Italy; 1.martini@abaperugia.org \\ + Presented at the International and interdisciplinary conference IMMAGINI? Image and Imagination \\ between representation, communication, education and psychology, Brixen, Italy, 27-28 November 2017.
}

Published: 1 December 2017

\begin{abstract}
In its archives, "Pietro Vannucci" Academy of Fine Arts has an imaginary Perugia consisting of drawings. The educational material, mostly unpublished, drawn up in the centuries by the students of the Schools of Architecture and Perspective regarding the Umbrian capital, depict views of a Calvinian city that does not exist. But at the same time they reveal an imaginary city that could have existed. Because they represent a series of interventions that radically transform their aspect from time to time, according to the cultural temperament of the execution period. These graphic exercises testify to the deep attention to the drawing experience intended as a tool of knowledge and prefiguration which took shape within the institution; their subject is a Perugia which serves as a scenario for a series of experiments aimed at determining its urban image.
\end{abstract}

Keywords: inventive drawing; image(s) of the city; Perugia

\section{Materials}

In its archives, "Pietro Vannucci" Academy of Fine Arts has an imaginary Perugia consisting of drawings [1-3] (Appendix A, 1). The educational material, mostly unpublished, drawn up in the centuries by the students of the Schools of Architecture and Perspective regarding the Umbrian capital, depict plan, elevation and perspective views of a Calvinian city that does not exist. But at the same time they reveal an imaginary city that could have existed. Because they represent a series of interventions that radically transform their aspect from time to time, according to the cultural temperament of the execution period, from 18th century neoclassicism to 19th and 20th century eclecticism to modern art of the 1930s. These graphic are the result of practice excercise, final essays, and competitions carried out during the teaching activities and testify to the choice of drawing as the main tool of knowledge and prefiguration adopted within the institution [4]. Their subject is a Perugia which acts as the scenario for experiments aimed at deepening occasionally assigned themes but which, like real "augmented drawings", prefigure a research on the urban image [5-7]. This study aims to describe this corpus from the point of view of the representation techniques used and the compositional choices underlying them, in order to disclose the inventive potential of a new city.

\section{Discussion}

The oldest graphic works by the teaching activity of the archives of the "Pietro Vannucci" Academy of Fine Arts of Perugia taken into consideration in this research date back to the late 18th century and witness the innovative tendencies that evolved under the direction of Baldassare Orsini [8-10]. Alongside some design solutions represented in a canonical manner, others are explored from 
the point of view of the theoretical compositions theorised by the scholar from Perugia [11]. Among the first ones, it is possible to describe that of Asclepiodoro Batocchi of 1798 for an entrance porch for the church of San Fortunato in Braccio Fortebraccio square in Perugia, "che accordi col bell'Arco etrusco della Via Vecchia", classically resembling a doric temple in antis (Appendix A, 2). At the same time, Filippo Pecci in 1795 drew in axonometry the elevation of the church of Sant'Angelo della Pace, adopting an unusual foreshortened point of view (Appendix A, 3). While Pietro Canali propose an "onamento" for the "arcadia" of the Frontone park (Appendix A, , 4) which echoes a doric monopteral temple of "architettura greca primigenia", that is also characterised by the semicircular plan and, above all, because of the emphasis given to the prospective perception of the artefact according to the Orsini architectural theories [14].

The didactic depth given by Orsini to the Perugine institution at the end of the 18th century is reflected decisively in the following century, and in this sense the drawings with which the students of the Schools of Architecture and Perspective participate in the competitions that conclude the years of course also reflect numerically the high interest that the Academy arouses in the city context. In particular, the projects testify to key points of learning based on drawing and, in particular, on copying Greek and Roman classics, although with a gradual introduction of dedicated courses that explore specific themes in depth such as architectural materials, building statics and construction technologies [15]. In addition, the study demonstrates the neoclassical character of the teachings given, but also shows the adoption of a more free eclectic language with neo-medieval and neorenaissance references, which still testify to the cultured and sought-after character of design solutions. They often are between emphatic and utopian as is sometimes the case in the learning context, but at the same time refer to the study of the facades of existing buildings as the most communicative and transformable element [16]. But the India ink and watercolour drawings of the Perugia Academy collection also testify a progressive centripetal tendency, to the point that the design themes are drawn from the unresolved urban problems of the Umbrian capital, and even in this sense the elaborated hypotheses have a decisive influence on the image of Perugia $[17,18]$. For example, Ludovico Scaccia in 1838 proposed a neoclassical solution for the unfinished facade of the church of Sant'Agostino that echoes the compositional themes of Giovanni Santini, a professor at the School of Architecture from 1833 to 1868 (Appendix A, 5). In fact, this facade is tripartite horizontally, where the lower band is bordered by smooth bugnato and the central part is retracted and characterised by two ionic parasta that support a decorated trabeation and centre a moulded portal, constituting a Renaissance reference in a context of architectural elements derived from GreekRoman classics. The upper band presents the use of a thermal window with bas-relief musician angels and is surmounted by a triangular pediment in which the tympanum houses the inscription of the place of worship [20]. Neoclassical themes are also adopted in the facade of the circular amphitheatre "per la città di Perugia", which Filippo Lardoni design in 1824 (Appendix A, 6). However, it is Leonello Serafini in particular who in 1846 conceive the neoclassical redraw of the entire east face of the current Giacomo Matteotti square, radically transforming one of the most well-known scenes of the Umbrian capital (Figure 1) (Appendix A, 7). 


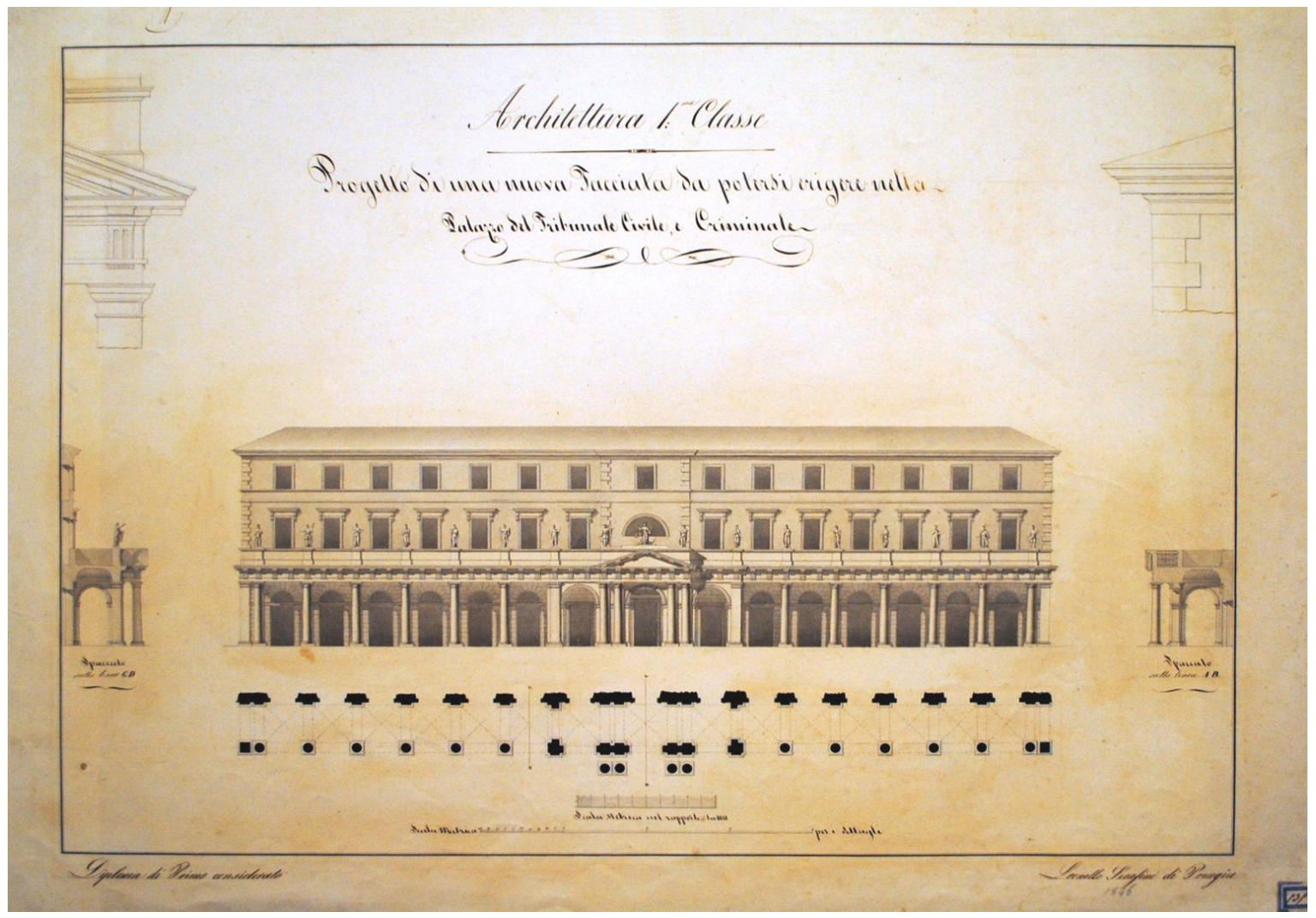

Figure 1. L. Serafini, Progetto di una nuova Facciata da potersi erigere nel Palazzo del Tribunale (...), 1846.

At the same time, some students acquired greater expressive freedom by adopting, in new projects and inventive redrawings, an eclectic style that echoes occasionally one or several historical periods according to the context or choices of the designer (Appendix A, 8). Emblematic in this sense is the hypothesis of Giovanni Tommaso Stamigni of 1849 where the main and lateral facades of the Perugia cathedral are completed in a Gothic style made of mullioned windows, cusps and pinnacles starting from the polylobed decoration of the existing basement and eliminating all the post 14th century superfetation such as the loggias of Braccio and the portals of Galeazzo Alessi and Pietro Carattoli (Figure 2) (Appendix A, 9). Therefore, it is evident that this facade is drawn to blend with the Priori palace and Maggiore fountain, to redefine the original character of the platea magna of the acropolis, though with a gothic exuberance that is definitely unusual in Perugia's context. However testifying how the reinterpretation of medieval language was one of the operating methods in architecture that will be most widely adopted in later years [24]. In addition, Venusto Mignini in 1897 scenically redrew the facade of the Turreno theatre through a serliana Mannerism theme composing one of the most well-known urban scenes of the Umbrian capital (Appendix A, 10). Or Fortunato Flamini who in 1848 proposed to renew the Augusta library, which at the time is located between the current Giuseppe Mazzini street and Giacomo Matteotti square, with a significantly eclectic code that provide a tripartite horizontal facade both dimensionally and figuratively (Appendix A, 11). Particularly in the lower part, a smooth ashlar wall texture is bordered by striped cushion bugnato, and there are kneeling windows and a portal framed by replied doric columns that support a moulded balcony, while in the middle band, the square stone masonry is bordered by smooth bugnato and the openings have a triangular tympanum. In the upper plastered part there is an inscription informing about its use as public library and a thermal window which centres a decorative apparatus of musician angels. It is actually the compositional freedom of Renaissance elements that characterises the lexical exuberance of this building. 


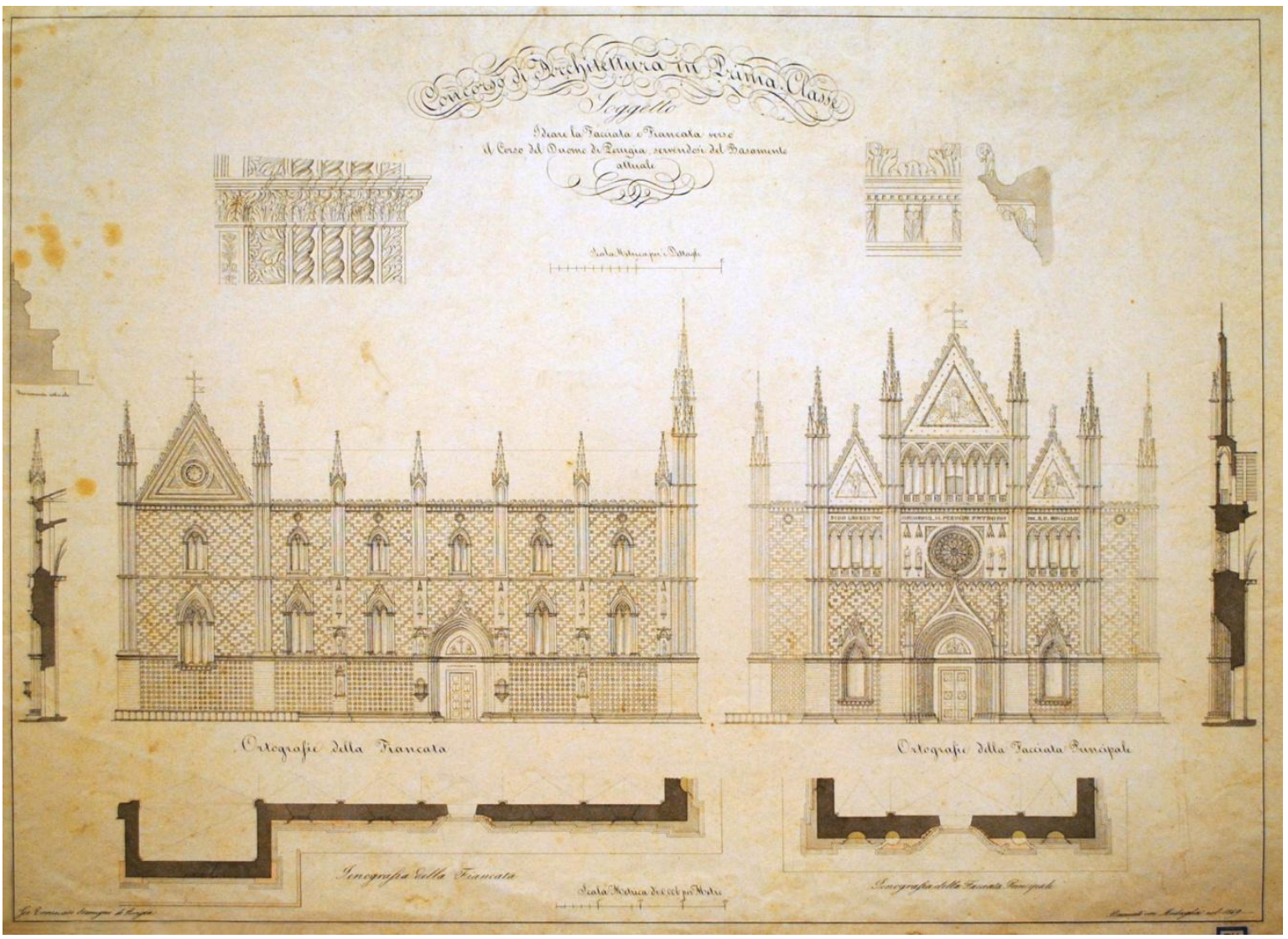

Figure 2. G.T. Stamigni, Ideare la Facciata e Fiancata verso il Corso del Duomo di Perugia (...), 1849.

In addition, drawings already express around the early 19th century functional themes, expanding the typological range and favouring greater social sharing and public application (Appendix A, 12). In this sense, in 1817 Alessio Starnari hypothesized an inn located in an unresolved context of the old town, such as del Sole street, where in 1891 the Turreno theatre was built (Appendix A, 13). Moreover, the lack of a contemporary city theatre is implicit in Annibale Angelini's hypothesis of 1830 for a "teatro diurno" (Appendix A, 14). The assigned area is that of the Frontone park precisely to promote accessibility, and the project propose terraces covered by a dome recalling that of the Pantheon covering a cylindrical volume, and which act as the pivot between a protruding entrance and a stage building dotted with moulded holes. The whole complex is surrounded by an ionic colonnade porch that is located on the front and an ashlar arch on the back. Likewise, the absence of public baths as a health and leisure resort is at the origin of the theme assigned to students in 1853 on the Pincetto cliff area. And Giovanni Pila who, in the place where in 1931 there would have been the covered market of Giuseppe Grossi, draws a rigorous building of smooth bugnato with a protruding entrance with "non troppo dispendiose comodità", illustrating an interesting functional reuse of one of the large arches nearby the medieval complex of Sopramuro (Appendix A, 15).

Besides, there are also the themes that fall into the so-called zero volume architecture (Appendix A, 16). For example, the Frontone park is the context for a burial monument to the condottiero and lord of Perugia Andrea Fortebraccio, which Annibale Boccanera conceived in 1828 on a podium on several levels connected by stairway ramps at first straight and then pincer shaped and dotted with statues, columns and celebratory friezes, which culminates in a dedicated sculptural group and which sets out scenographically the embankment in the area (Appendix A, 17). In 1834, also Napoleone Cherubini, taking into account the urban morphology, designed two circular basin twin fountains for the Fortezza square, as they are placed iconically in the visual cone that connects the current Baglioni street and corso Vannucci with the facade of the rocca Paolina fortress overlooking the square (Appendix A, 18). Also very significant for the repercussions on the city's image is the "Decorazione" carry out for the "Festività", proposed by Lardoni in 1823 (Figure 3) (Appendix A, 19). Unfortunately, in the archives of the Perugine institution it is possible to find only a planimetric 
map of this proposal, but this suggests that the scenic apparatus involves the whole area of the current Giacomo Matteotti square and Baglioni street, transforming the facades with decorated screenings that appear as scenic entrances near the accesses.

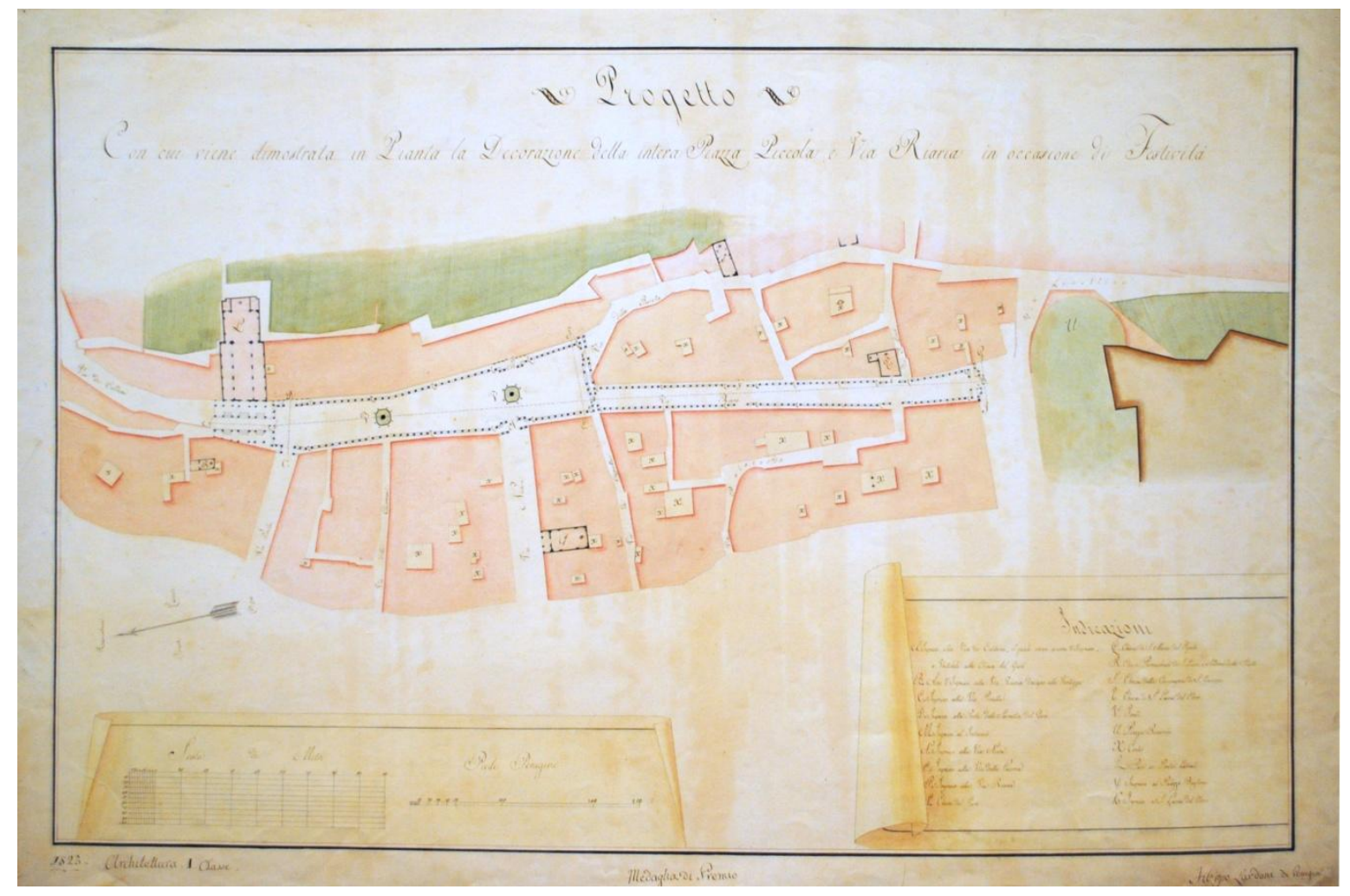

Figure 3. F. Lardoni, (...) Decorazione dell'intera Piazza Piccola e Via Riaria in occasione di Festività, 1823.

Nowadays we readily acknowledge the decisive role played by professors and students in the architectural evolution of the Perugian capital between the 19th and 20th centuries [24] (pp. 38, 50, n. 8). In particular, a large number of students, after completing their studies, contribute with their professional activity to transform its appearance, like Nazareno Biscarini, Guglielmo Calderini and Giovanni Santini just to mention a few (Appendix A, 20). In this sense, the fundamental role of the drawings, considered as a prelude to projects that in later years would have involved Perugia's town centre is evident. For example, after the second half of the 19th century, the general focus converged on a type of research mostly concerned with urban developments regarding the problems arising from Italy's post-unification transformation. In this context there are few images, such as Flaminio Rotondi's perspective of 1878 for the study of the location of the new monument to Vittorio Emanuele II, that evoke the new contemporary city so effectively (Figure 4) (Appendix A, 21). In fact, the historical platea magna is not visible at the observer's back, and the equestrian statue of the new sovereign stands in the background, just before the horizon on the Umbrian hills, which appears framed by the prospect of the innovative scenes of the Provincia palace by Alessandro Arienti and the headquarters of the Bank of Italy by Guglielmo Rossi, both conceived in 1873. 


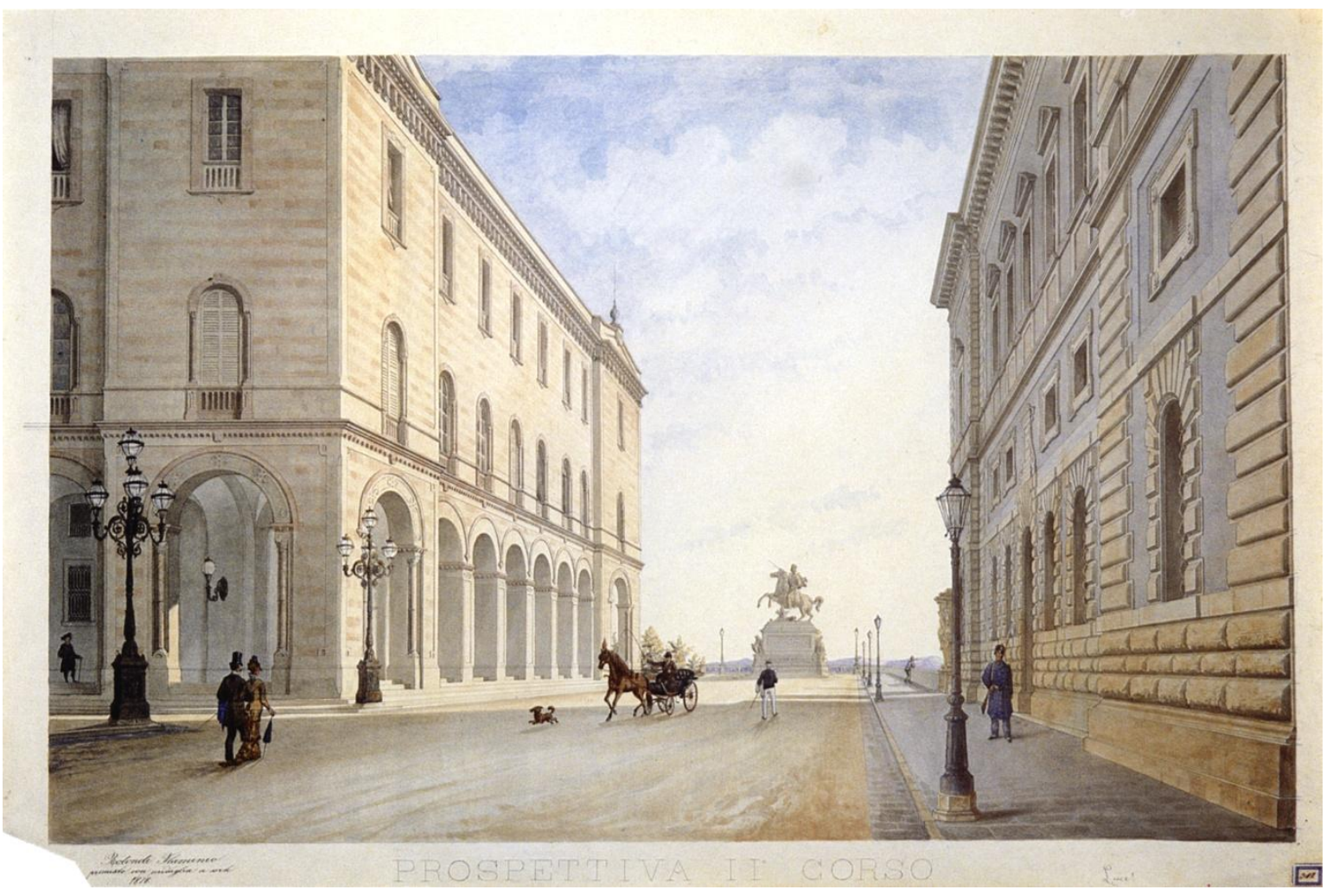

Figure 4. F. Rotondi, Perspective of the monument to Vittorio Emanuele II (...), 1878.

With the advent of the 20th century there is a gradual change of the subjects covered by the students and the styles adopted. And if during the architecture lectures given by Giuseppe Odoni and Ugo Tarchi the compositional themes are always addressed in an antique and eclectic framework, it is with the latter that we assist to the introduction of "misurazione" and "restauro" (Appendix A, 22), which besides consecrating scientific drawing as a tool of knowledge, open up to the new themes that are making their way in Italy and over the world [30]. It is with professors Pietro Angelini and, above all, Manfredi Franco that the Academy opened up to a modern change that could have deeply modified the image of the Umbrian capital [30]. For example, Rodi Palazzetti in 1935 proposed an entrance made of horizontal levels for the stadium, marked by two helical stairs crossing two semi-circular panoramic viewpoints on the first level and the accessible roofing, both provided with a linear parapet recalling naval architecture (Figure 5). While the horizontality of the terraces is contradicted by the verticality of a stereometric tower with tight vertical openings (Appendix A, 23). On the other hand, Alberto Biganti in 1938 designed a station which is a parallelepiped volume in which the entrance is ordered by four rectangular pillars that go full height through the roofing, which becomes a thin platform supported by two lateral blocks characterised by circular openings (Figure 6). In addition, the interior is marked by communication walls that provide information to travellers through dedicated minimal graphics (Appendix A, 24). 


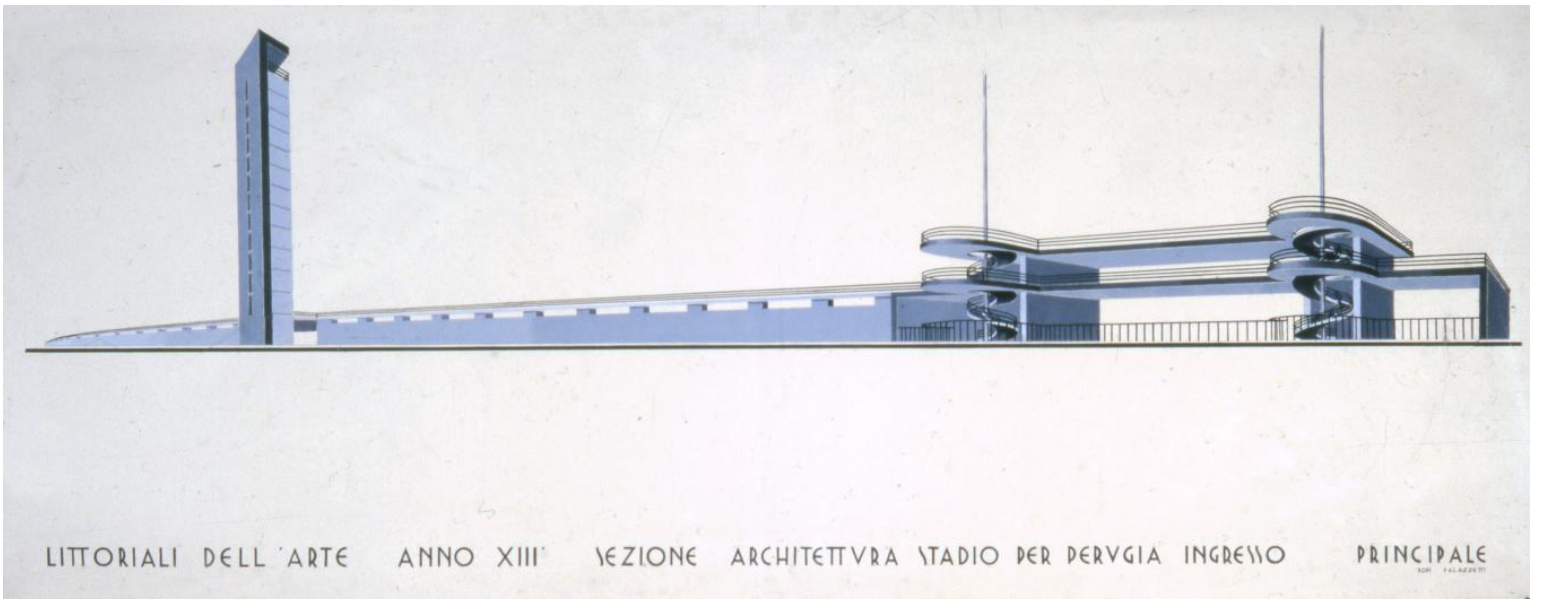

Figure 5. R. Palazzetti, Stadio per Perugia, 1935.

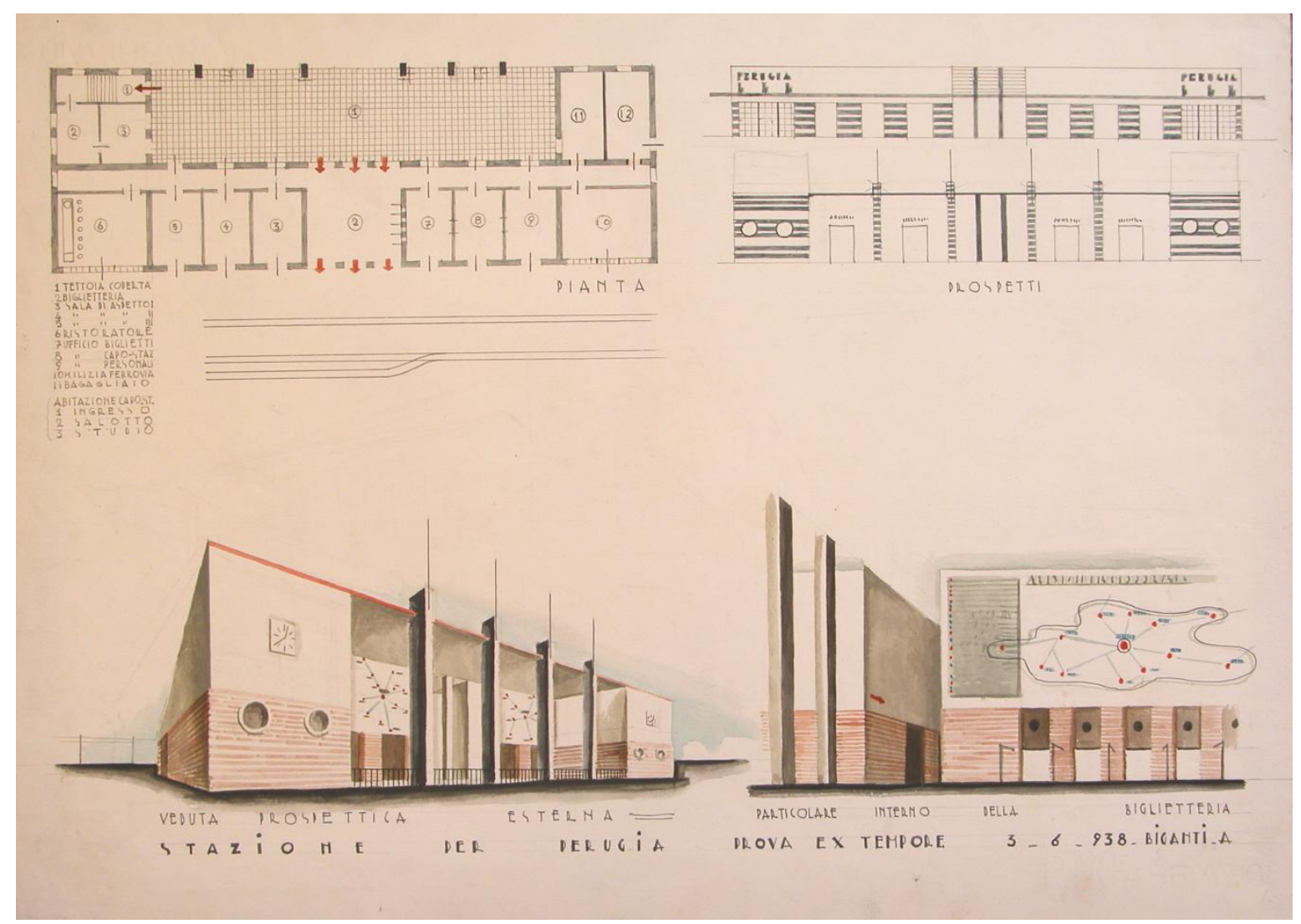

Figure 6. A. Biganti, Stazione per Perugia, 1938.

\section{Conclusions}

Unfortunately, the concrete possibility for a group of modern Umbrian designers to be formed is nipped in the bud during the 1938-1939 biennium by the ministerial reform that establish the present-day degree issued by universities and polytechnics, depriving the Perugia Academy of its Architecture chair. In this sense, the innovative buildings that dotted the city in those years were not related to any school, and this contributed to fuelling the common thought of a region that is only touched lightly by modernity $[32,33]$. Looking at the thread that in the 19th century joins academic teaching and urban image, and bearing in mind that such an image exists first and foremost in the education of the observer who attributes value or not to certain signs, it is plainly plausible that a rooted Academy like that of Perugia could have formed good designers open to new ways of composing. In addition, it could have fed the awareness of a "contemporary doing" on all levels of the construction chain, from the customer to the contractor through public administration, resulting 
in an architectural development path at least in part different from what started, or perhaps gone the wrong way, between the second world war. Because if it is true that young designers are now faced with the real needs of the context in order to respond with images to social demand expressed by the territory, it has always been known that the representation of an imagined city prefigures the image of the built city, as evidenced by the drawings of the Academy of Perugia.

Conflicts of Interest: The author declares no conflict of interest.

\section{Appendix A}

1. I would like to thank the Director of the Academy of Perugia, professor Paolo Belardi, for his precious research ideas and Fedora Boco, B. A., and Elisabetta Passerini, B. A., for the continued availability shown during archival consultations.

2. See Asclepiodoro Batocchi, Portico ideato alla chiesa di S. Fortunato in Piazza Grimana (...), 1798, plan and elevation, India ink and watercolour, $75 \times 48 \mathrm{~cm}$ (Perugia, Archive of the "Pietro Vannucci" Academy of Fine Arts, School of Architecture educational Fonds, inv. 26). See also Scipione Antonini, Pianta topografica del Frontone considerando gli abbellimenti che già ci sono e quelli che si potrebbero aggiungere (...), 1792, site plan, India ink and watercolour, $100 \times 64 \mathrm{~cm}$ (Perugia, Archive of the "Pietro Vannucci" Academy of Fine Arts, School of Architecture Educational Fund, inv. 7).

3. See Filippo Pecci, Lato della Chiesa di S. Angiolo di Porta Sole, 1795, axonometry, India ink and watercolour, $47 \times 65 \mathrm{~cm}$ (Perugia, Archive of the "Pietro Vannucci" Academy of Fine Arts, School of Architecture educational Fonds, inv. 14). Filippo is the brother of Vincenzo Gioacchino Pecci (future Pope Leo XIII), then pupil of Orsini and later Academician of Merit in 1804 and professor at the School of Perspective of the Academy of Perugia from 1810 to 1814 [12].

4. See Pietro Canali, Ornamento per l'arcadia del Frontone (...), 1796, plan and perspective, India ink and watercolour, $78 \times 50 \mathrm{~cm}$ (Perugia, Archive of the "Pietro Vannucci" Academy of Fine Arts, School of Perspective educational Fonds, inv. 10). Canali became a key figure in the Academic events of the first half of the 19th century: after being a pupil of Orsini, he was subsequently Academician of Merit in 1797, professor of the School of Architecture from 1810 to 1814 and Director of the Academy of Perugia from 1829 to 1841 [13].

5. See Ludovico Scaccia, Progetto per l'ortografia esterna del tempio di S. Agostino in Perugia, 1838, elevation, India ink and watercolour, $120 \times 68 \mathrm{~cm}$ (Perugia, Archive of the "Pietro Vannucci" Academy of Fine Arts, School of Architecture educational Fonds, inv. 402) [19].

6. See Filippo Lardoni, Prospetto dell'Anfiteatro (...), 1824, section and elevation, India ink and watercolour, $71 \times 109 \mathrm{~cm}$ (Perugia, Archive of the "Pietro Vannucci" Academy of Fine Arts, School of Architecture educational Fonds, inv. 145). Lardoni was chief civil engineer of the Perugia Municipality from the second half of the thirties to 1864, and in this role he designed a series of public buildings in Perugia, among which the slaughterhouse (currently the Department of Jurisprudence of the University of Perugia) and the door of Santa Croce (so-called Three Arches) [20,21].

7. See Leonello Serafini, Progetto di nuove Facciate da potersi erigere nella Chiesa e Casa del Gesù, 1846, elevations, plans, section and details, India ink and watercolour, $70 \times 130 \mathrm{~cm}$ (Perugia, Archive of the "Pietro Vannucci" Academy of Fine Arts, School of Architecture educational Fonds, inv. 536) and Leonello Serafini, Progetto di una nuova Facciata da potersi erigere nel Palazzo del Tribunale Civile e Criminale, 1846, elevation, plan, sections and details, India ink and watercolour, $70 \times 101$ cm (Perugia, Archive of the "Pietro Vannucci" Academy of Fine Arts, School of Architecture educational Fonds, inv. 535) [22].

8. For example, see the following drawings: Giuseppe Simelli, Progetto per la facciata della chiesa di S. Domenico di Perugia, 1803, elevation and plan, India ink and watercolour, $79 \times 54 \mathrm{~cm}$ (Perugia, Archive of the "Pietro Vannucci" Academy of Fine Arts, School of Architecture educational Fonds, inv. 40); Fiorenzo Cherubini, Prospetto e Spaccato del Monumento ideato a Braccio Fortebracci, 1828, elevation and section, India ink and watercolour, $65 \times 94 \mathrm{~cm}$ (Perugia, Archive of the 
"Pietro Vannucci" Academy of Fine Arts, School of Perspective educational Fonds, inv. 230); Gregorio Amadei, Piazza del Domo di Perugia veduta dalla parte del Vescovato, 1832, perspective, India ink and watercolour, $57 \times 81 \mathrm{~cm}$ (Perugia, Archive of the "Pietro Vannucci" Academy of Fine Arts, School of Perspective educational Fonds, inv. 72); Nilo Venti, Porta di S. Pietro in Perugia giusta i documenti esistenti, 1869, perspective, India ink and watercolour, $110 \times 81 \mathrm{~cm}$ (Perugia, Archive of the "Pietro Vannucci" Academy of Fine Arts, School of Perspective educational Fonds, inv. 244); Carlo Francisci, Perspective of Sant'Angelo's temple with colonnade, 1871, perspective, India ink and watercolour, $83 \times 111 \mathrm{~cm}$ (Perugia, Archive of the "Pietro Vannucci" Academy of Fine Arts, School of Perspective educational Fonds, inv. 262); Roberto Sartoretti, Progetto di completamento della facciata della chiesa dei Scalzi in Perugia, 1887, elevation, plan and details, India ink and watercolour, $103 \times 71 \mathrm{~cm}$ (Perugia, Archive of the "Pietro Vannucci" Academy of Fine Arts, School of Architecture educational Fonds, inv. 1134) e Edoardo Vignaroli, Reconstruction hypothesis of Valentino Martelli's porch in Sopramuro square, 1887, elevation and plan, India ink and watercolour, $59 \times 91 \mathrm{~cm}$ (Perugia, Archive of the "Pietro Vannucci" Academy of Fine Arts, School of Architecture educational Fonds, inv. 943).

9. See Giovanni Tommaso Stamigni, Ideare la Facciata e Fiancata verso il Corso del Duomo di Perugia, servendosi del Basamento attuale, 1849, elevations, plans, sections and details, India ink and watercolour, $68 \times 92 \mathrm{~cm}$ (Perugia, Archive of the "Pietro Vannucci" Academy of Fine Arts, School of Architecture educational Fonds, inv. 571 bis). Note that even Stamigni's teacher, Santini, intervened in those years in the internal reconfiguration of the Perugia cathedral, adopting the same language [20]. In addition, Stamigni collaborated with the academy several times in the courses held by Santini between 1857 and 1862 [23].

10. See Venusto Mignini, Project of the facade of the Turreno theatre, 1897, elevation, India ink and watercolour, $63 \times 89 \mathrm{~cm}$ (Perugia, Archive of the "Pietro Vannucci" Academy of Fine Arts, School of Architecture educational Fonds, inv. 1298) [25].

11. See Fortunato Flamini, Redraw of the Augusta library building, 1848, elevation and details, India ink and watercolour, $65 \times 88 \mathrm{~cm}$ (Perugia, Archive of the "Pietro Vannucci" Academy of Fine Arts, School of Architecture educational Fonds, inv. 559).

12. For example, see the following drawings: Vincenzo Ciofi, Pianta (...) presso la Fortezza di Perugia (...) da ridursi ad uso di Anfiteatro (...), 1802, plan and section, India ink and watercolour, $50 \times 71$ cm (Perugia, Archive of the "Pietro Vannucci" Academy of Fine Arts, School of Architecture educational Fonds, inv. 35); Francesco Biancalana, Prospetto esteriore dell'Ospedale (...), 1822, elevation and section, India ink and watercolour, $67 \times 111 \mathrm{~cm}$ (Perugia, Archive of the "Pietro Vannucci" Academy of Fine Arts, School of Architecture educational Fonds, inv. 127); Giovanni Santini, Progetto di un Bagno Pubblico da costruirsi in San Galgano, 1827, elevation and section, India ink and watercolour, $71 \times 88 \mathrm{~cm}$ (Perugia, Archive of the "Pietro Vannucci" Academy of Fine Arts, School of Architecture educational Fonds, inv. 194); Vincenzo Baldini, Ortografia Esterna del Bagno Medicinale e di Delizia, 1827, elevation and sections, India ink and watercolour, $70 \times 88 \mathrm{~cm}$ (Perugia, Archive of the "Pietro Vannucci" Academy of Fine Arts, School of Architecture educational Fonds, inv. 210); Alessio Starnari, (...) Fabbricato (...) per uso di Bagni, 1830, section, elevation and plan, India ink and watercolour, $71 \times 52 \mathrm{~cm}$ (Perugia, Archive of the "Pietro Vannucci" Academy of Fine Arts, School of Architecture educational Fonds, inv. 261); Geremia Innamorati, Project of a market square in the vegetable garden area of Oddi house, 1839, sections and elevations, India ink and watercolour, $78 \times 105 \mathrm{~cm}$ (Perugia, Archive of the "Pietro Vannucci" Academy of Fine Arts, School of Architecture educational Fonds, inv. 428); Giuseppe Ortis, Ortografia interna della Dogana (...), 1839, section and elevation, India ink and watercolour, $58 \times 76 \mathrm{~cm}$ (Perugia, Archive of the "Pietro Vannucci" Academy of Fine Arts, School of Architecture educational Fonds, inv. 417); Belisario Simonelli, Progetto d'una Piazza di Mercato da stabilirsi nell'Orto e Fabbricati lungo la Via Oradina, 1839, plan, India ink and watercolour, $68 \times 94$ cm (Perugia, Archive of the "Pietro Vannucci" Academy of Fine Arts, School of Architecture educational Fonds, inv. 437). 
13. See Alessio Starnari, Pianta, Elevato e Sezione della nuova Locanda, 1817, site plan, elevation and section, India ink and watercolour, $72 \times 105 \mathrm{~cm}$ (Perugia, Archive of the "Pietro Vannucci" Academy of Fine Arts, School of Architecture educational Fonds, inv. 101).

14. See Annibale Angelini, Teatro diurno da costruirsi nel Pubblico Passaggio del Frontone, 1830, sections and elevations, India ink, watercolour and pencil, $109 \times 74 \mathrm{~cm}$ (Perugia, Archive of the "Pietro Vannucci" Academy of Fine Arts, School of Architecture educational Fonds, inv. 263) [26].

15. See Giovanni Pila, Project of public baths in the Pincetto area, 1853, site plan, profile and details, India ink and watercolour, $66 \times 101 \mathrm{~cm}$ (Perugia, Archive of the "Pietro Vannucci" Academy of Fine Arts, School of Architecture educational Fonds, inv. 683) e Giovanni Pila, Ideare una fabbrica ad uso di Bagni (...) negli Orti sottoposti alla Chiesa del Gesù, 1853, elevations and sections, India ink and watercolour, $69 \times 99 \mathrm{~cm}$ (Perugia, Archive of the "Pietro Vannucci" Academy of Fine Arts, School of Architecture educational Fonds, inv. 681).

16. For example, see the following drawings: Silvestro Massari, Project of a triumphal arch in the area of the rocca Paolina fortress, 1817, perspective, India ink and watercolour, $72 \times 95 \mathrm{~cm}$ (Perugia, Archive of the "Pietro Vannucci" Academy of Fine Arts, School of Perspective educational Fonds, inv. 33); Filippo Lardoni, Project of a triumphal arch, 1821, perspective, India ink and watercolour, $56 \times 62 \mathrm{~cm}$ (Perugia, Archive of the "Pietro Vannucci" Academy of Fine Arts, School of Perspective educational Fonds, inv. 38); Gregorio Amadei, Project of a fountain in the area of the church of Sant'Ercolano, 1834, plan and elevation, India ink and watercolour, $79 \times 56 \mathrm{~cm}$ (Perugia, Archive of the "Pietro Vannucci" Academy of Fine Arts, School of Architecture educational Fonds, inv. 319); Emanuele Civi, Ingresso ideato per il pubblico Passeggio del Frontone di Perugia, 1838, perspective, India ink and watercolour, $64 \times 89 \mathrm{~cm}$ (Perugia, Archive of the "Pietro Vannucci" Academy of Fine Arts, School of Perspective educational Fonds, inv. 104).

17. See Annibale Boccanera, Project of a burial monument to Braccio Fortebraccio in the area of the Frontone park, 1828, elevation, India ink and watercolour, $71 \times 110 \mathrm{~cm}$ (Perugia, Archive of the "Pietro Vannucci" Academy of Fine Arts, School of Architecture educational Fonds, inv. 220).

18. See Napoleone Cherubini, Project of two fountains for the Fortezza square and the area of the church of Sant'Ercolano, 1834, site plan, plan and section, India ink and watercolour, $66 \times 91 \mathrm{~cm}$ (Perugia, Archive of the "Pietro Vannucci" Academy of Fine Arts, School of Architecture educational Fonds, inv. 328). See also Napoleone Cherubini, Pianta delle due Fontane da situarsi nella Piazza della Fortezza (...), 1834, plans, India ink and watercolour, $95 \times 67 \mathrm{~cm}$ (Perugia, Archive of the "Pietro Vannucci" Academy of Fine Arts, School of Architecture educational Fonds, inv. 329) [27].

19. See Filippo Lardoni, Progetto Con cui viene dimostrata in Pianta la Decorazione dell'intera Piazza Piccola e Via Riaria in occasione di Festività, 1823, site plan, India ink and watercolour, $41 \times 64 \mathrm{~cm}$ (Perugia, Archive of the "Pietro Vannucci" Academy of Fine Arts, School of Architecture educational Fonds, inv. 135).

20. In addition, Santini was a professor of the School of Architecture from 1833 to 1868 and of the School of Perspective from 1834 to 1850, Calderini was a professor of the School of Architecture from 1868 to 1882 and Biscarini was a professor of the School of Architecture from 1884 to 1898 [28,29].

21. See Flaminio Rotondi, Perspective of the monument to Vittorio Emanuele II in the Carducci gardens area, 1878, perspective, India ink and watercolour, $73 \times 109 \mathrm{~cm}$ (Perugia, Archive of the "Pietro Vannucci" Academy of Fine Arts, School of Perspective educational Fonds, inv. 302). Perspective drawings in the archive usually are in two points and one point representations, while the height from the ground of the viewpoint varies occasionally. In this case, the representation is a frontal perspective with a point of view placed at a height comparable to that of a person standing to help the observer to identify itself in the scene.

22. For example, see the following drawings: Lea Verdesi, Misurazione dal vero della facciata della chiesa Nuova in Perugia, 1912, elevation and plan, India ink and watercolour, $187 \times 130 \mathrm{~cm}$ (Perugia, Archive of the "Pietro Vannucci" Academy of Fine Arts, School of Architecture 
educational Fonds, inv. 1392) e Vincenzo Esposito, Restauro e ripristino della chiesa di Santo Stefano in Perugia, 1918, elevation, India ink, $173 \times 143 \mathrm{~cm}$ (Perugia, Archive of the "Pietro Vannucci" Academy of Fine Arts, School of Architecture educational Fonds, inv. 1395).

23. See Rodi Palazzetti, Stadio per Perugia, 1935, perspective, India ink and watercolour, $72 \times 180 \mathrm{~cm}$ (Perugia, Archive of the "Pietro Vannucci" Academy of Fine Arts, School of Architecture educational Fonds, inv. 1084) [31].

24. Alberto Biganti, Stazione per Perugia, 1938, plan, elevations and prospettive, India ink and watercolour, $35 \times 48 \mathrm{~cm}$ (Perugia, Archive of the "Pietro Vannucci" Academy of Fine Arts, School of Architecture educational Fonds, inv. 1194).

\section{References}

1. Boco, F.; Ponti, A.C. (Eds.) L'Accademia Riflette Sulla sua Storia. Perugia e le Origini dell'Accademia del Disegno. Secoli XVI e XVII; Futura: Perugia, Italy, 2011; ISBN 9788897720034.

2. Muratore, G.; Boco, F. (Eds.) Scuola e Architettura. L'evoluzione del Disegno Architettonico dal 1790 al 1940 Nelle Raccolte dell'Accademia di Belle Arti di Perugia; Benucci: Perugia, Italy, 1989.

3. Boco, F. Progettare la città. I disegni della Scuola di Architettura e Prospettiva dell' Accademia di Belle Arti di Perugia. In Arteincittàd'arte; Litograf: Todi, Italy, 2006; pp. 7-9.

4. Muratore, G.; Boco, F. (Eds.) Saggi finali e temi di concorso. In Scuola e Architettura. L'evoluzione del Disegno Architettonico dal 1790 al 1940 Nelle Raccolte dell'Accademia di Belle Arti di Perugia; Benucci: Perugia, Italy, 1989; pp. 177-207.

5. Lynch, K. L'immagine della Città; Marsilio: Venezia, Italy, 2004; ISBN 9788831772678.

6. Volta, V. (Ed.) Immagine della Città Europea; Tamellini: Legnago, Italy, 2005.

7. Marotta, A.; Novello, G. (Eds.) Disegno \& Città. Cultura, Arte, Scienza, Informazione; Gangemi Editore: Roma, Italy, 2015; ISBN 9788849231243.

8. Lenza, C.; Trombetta, V. (Eds.) Baldassarre Orsini. Tra Arte e Scienza (1732-1810); Silvana Editoriale: Milano, Italy, 2017; ISBN 9788836637188.

9. Belardi, P. (Ed.) Baldassarre Orsini (1732-1810). Profilo bio-bibliografico. In Dell'Architettura Civile di Baldassarre Orsini. Parte Seconda; Officina Edizioni: Roma, Italy, 2008; pp. 19-42, ISBN 9788860490506.

10. Boco, F. Disegni di Architettura e di Prospettiva degli allievi dell'Accademia del Disegno. In Baldassarre Orsini. Tra Arte e Scienza (1732-1810); Lenza, C., Trombetta, V., Eds.; Silvana Editoriale: Milano, Italy, 2017; pp. 182-183, ISBN 9788836637188.

11. Belardi, P.; Boco, F. "Coniurant amice". Baldassarre Orsini e la riforma dell'Accademia. In Baldassarre Orsini. Tra Arte e Scienza (1732-1810); Lenza, C., Trombetta, V., Eds.; Silvana Editoriale: Milano, Italy, 2017; pp. 148-155, ISBN 9788836637188.

12. Muratore, G.; Boco, F. (Eds.) Pecci Filippo. In Scuola e Architettura. L'evoluzione del Disegno Architettonico dal 1790 al 1940 nelle Raccolte dell' Accademia di Belle Arti di Perugia; Benucci: Perugia, Italy, 1989; p. 63.

13. Muratore, G.; Boco, F. (Eds.) Canali Pietro. In Scuola e Architettura. L'evoluzione del Disegno Architettonico dal 1790 al 1940 nelle Raccolte dell'Accademia di Belle Arti di Perugia; Benucci: Perugia, Italy, 1989; p. 63.

14. Belardi, P. (Ed.) Dell'Architettura civile di Baldassarre Orsini. La centralità del disegno nella composizione architettonica. In Dell'Architettura Civile di Baldassarre Orsini. Parte Seconda; Officina Edizioni: Roma, Italy, 2008; pp. 43-53, ISBN 9788860490506.

15. Cauti, A. L'insegnamento dell'architettura all'Accademia di Perugia. In Scuola e Architettura. L'evoluzione del Disegno Architettonico dal 1790 al 1940 nelle Raccolte dell'Accademia di Belle Arti di Perugia; Muratore, G., Boco, F., Eds.; Benucci: Perugia, Italy, 1989; pp. 45-48.

16. Boco, F. Quando la Storia entra in Accademia. In Scuola e Architettura. L'evoluzione del Disegno Architettonico dal 1790 al 1940 nelle Raccolte dell'Accademia di Belle Arti di Perugia; Muratore, G., Boco, F., Eds.; Benucci: Perugia, Italy, 1989; pp. 15-24.

17. Belardi, S.; Bori, S. (Eds.) 1861-1939. L'architettura della Perugia Postunitaria; Fabrizio Fabbri Editore: Perugia, Italy, 2013; ISBN 9788867780020.

18. Belardi, P. Profilo storico dell'architettura umbra dell'Ottocento. Dal palazzo Comunale di Foligno al palazzo del Governo di Perugia. In 1861-1939. L'architettura della Perugia Postunitaria; Belardi, S., Bori, S., Eds.; Fabrizio Fabbri Editore: Perugia, Italy, 2013; pp. 23-49, ISBN 9788867780020.

19. Migliorati, A. Ludovico Scaccia. In Dall'Illuminismo al Novecento. Disegni di Architettura e Prospettiva. Accademia di Belle Arti Pietro Vannucci; Deltagrafica: Città di Castello, Italy, 1995; p. 7. 
20. Belardi, P.; Martini, L. Giovanni Santini (1802-1868). In 1861-1939. L'architettura della Perugia Postunitaria; Belardi, S., Bori, S., Eds.; Fabrizio Fabbri Editore: Perugia, Italy, 2013; pp. 125-139, ISBN 9788867780020.

21. Migliorati, A. Filippo Lardoni. In Dall'Illuminismo al Novecento. Disegni di Architettura e Prospettiva. Accademia di Belle Arti Pietro Vannucci; Deltagrafica: Città di Castello, Italy, 1995; p. 6.

22. Migliorati, A. Lionello Serafini. In Dall'Illuminismo al Novecento. Disegni di Architettura e Prospettiva. Accademia di Belle Arti Pietro Vannucci; Deltagrafica: Città di Castello, Italy, 1995; p. 8.

23. Migliorati, A. Giovanni Tommaso Stamigni. In Dall'Illuminismo al Novecento. Disegni di Architettura e Prospettiva. Accademia di Belle Arti Pietro Vannucci; Deltagrafica: Città di Castello, Italy, 1995; pp. 8-9.

24. Belardi, P.; Menchetelli, V. L'architettura della Perugia postunitaria 1861-1911. Dalla città aristocratica alla città borghese. In Il Palazzo Cesaroni di Perugia; Mancini, F.F., Ed.; Quattroemme: Perugia, Italy, 2011; pp. 35-52, ISBN 9788889398708.

25. Migliorati, A. Venusto Mignini. In Dall'Illuminismo al Novecento. Disegni di Architettura e Prospettiva. Accademia di Belle Arti Pietro Vannucci; Deltagrafica: Città di Castello, Italy, 1995; p. 11.

26. Salvo, S. Pietro Angelini (1892-1985). In 1861-1939. L'architettura della Perugia Postunitaria; Belardi, S., Bori, S., Eds.; Fabrizio Fabbri Editore: Perugia, Italy, 2013; p. 291, ISBN 9788867780020.

27. Migliorati, A. Napoleone Cherubini. In Dall'Illuminismo al Novecento. Disegni di Architettura e Prospettiva. Accademia di Belle Arti Pietro Vannucci; Deltagrafica: Città di Castello, Italy, 1995; p. 7.

28. Muratore, G.; Boco, F. (Eds.) I Professori della Scuola di Architettura dal 1791 al 1939. In Scuola e Architettura. L'evoluzione del Disegno Architettonico dal 1790 al 1940 nelle Raccolte dell'Accademia di Belle Arti di Perugia; Benucci: Perugia, Italy, 1989; p. 61.

29. Muratore, G.; Boco, F. (Eds.) I Professori della Scuola di Prospettiva dal 1790 al 1922. In Scuola e Architettura. L'evoluzione del Disegno Architettonico dal 1790 al 1940 nelle Raccolte dell'Accademia di Belle Arti di Perugia; Benucci: Perugia, Italy, 1989; p. 61.

30. Belardi, P. «Povera architettura nostra!». La ventata razionalista dell' Accademia del Disegno di Perugia. Ikhnos. Analisi grafica e storia della rappresentazione 2010, 1, 119-128.

31. Migliorati, A. Rodi Palazzetti. In Dall'Illuminismo al Novecento. Disegni di Architettura e Prospettiva. Accademia di Belle Arti Pietro Vannucci; Deltagrafica: Città di Castello, Italy, 1995; p. 13.

32. Belardi, P. (Ed.) L'altra modernità. L'architettura in Umbria tra le due guerre. In Semplice Semplice ma Italiano Italiano. Architettura Moderna in Umbria; Edizioni Orfini Numeister: Foligno, Italy, 2011; pp. 55-65, ISBN 9788889274200.

33. Belardi, P. (Ed.) L'Umbria e la sindrome da Mulino Bianco. In NAU. Novecento Architettura Umbria; Il Formichiere: Foligno, Italy, 2014; pp. 281-283, ISBN 9788898428144.

(C) 2017 by the authors. Licensee MDPI, Basel, Switzerland. This article is an open access article distributed under the terms and conditions of the Creative Commons Attribution (CC BY) license (http://creativecommons.org/licenses/by/4.0/). 